\title{
THE CLINICAL SIGNIFICANCE OF THE TOTAL AND FREE TESTOSTERONE IN AGING MEN
}

\author{
S.I.Enany*, H.T. Kandeel** N. Abd-El-Lateef***, and M. Hussein**** \\ Urology*, Endocrinology** Radio diagnosis***, and Clinical Pathology**** \\ Faculty of medicine Al-Azhar University
}

\begin{abstract}
The aim of this study is to evaluate the clinical significance of the total and free testosterone in aging men. This study was carried out on 45 healthy men. They were divided into three groups, according to the age, each group contains 15 men. Group I: age ranged from 50-60 years. Group II: From 61-70 years and Group III: From 71-85 years. For each subject, history was taken and clinical examination, routine laboratory investigations: total and free testosterone levels, also total and free prostate specific antigen (PSA). Transrectal ultrasonography (TRUS) was done. Bone densitometry by ultrasonography also done. Our results revealed that, the mean values of the total and free testosterone levels were progressively decline with increasing age. The lowest levels of total and free testosterone were found in-group III, but these lowest levels were still at the accepted normal range. The mean values of the total and free PSA levels in the different three studied groups were progressively increased with aging men, but its levels were still within the normal range. There was positive correlation between the total and free levels of testosterone. Also positive correlation was found between the total and free PSA values. Additionally an inverse relationship was found between testosterone levels either total or free with PSA values. Erectile function declined significantly by age, the worst was group III with significant correlation with the level of total and free testosterone in the three studied groups. In this work the broadband ultrasound attenuation (BUA) in-group II was significantly lower than group I $(\mathrm{p}<0.001)$ but insignificant difference between group II and group III. Relative Risk Fracture (RRF) in-group II was significantly increased compared to group I ( $p>0.003$ ), but insignificant difference between groups II and group III ( $p>0.998)$.T-score was significantly lower in group II and III compared to group I $,(\mathrm{p}<0.001),(\mathrm{p}<0.02)$ for both respectively. Z-score showed highly significant reduction in groups II and III compared to group I $(\mathrm{p}<0.000)$ for both of them. While, non-significant differences between group II and III regarding T and Z-score $(\mathrm{p}>0.38),(\mathrm{p}>0.554)$ respectively. Correlation between free (FT) and total (TT) testosterone, with bone densitometry, there were positive correlation between (FT) versus BUA, T and Z-score. It was positively correlated between (TT) versus BUA and T-score only, while the correlation of both was negative with RRF.

We concluded that, total and free testosterone progressively decline with aging. It was associated with progressive increase in the level of total and free PSA. These findings were associated with progressive decline in erectile function. Bone mineral density decreased gradually with increasing age, and increased incidence of bone fracture.
\end{abstract}

\section{Introduction}

In men there are progressive declining in androgen production associated with aging. This phenomenon has been named male climacteric, andropause or more appropriately, androgen decline in aging male (1). Aging is associated with alteration in many hormonal levels in general, particularly in androgens, which has

significant low level. These hormonal changes require further researches and acceptance by the medical community (2). Therefore, urologists and endocrinologist should view the elderly men who constitute such a large component of everyday practice as patients with more than specific genitourinary and endocrinal complaints. 


\section{S.I.Enany $\boldsymbol{e t}$ al}

The nature of such complaints may be directly related to the hormonal environment. A relevant example is the effects of androgen ablation in men with prostate cancer on bone mineral metabolism (3\&4) and sleep patterns (5). The magnitude of the decline in testosterone with age and the prevalence of older men with low testosterone levels have not been well established (6). So the aim of our study is to evaluate the clinical significance of the total and free testosterone levels in aging men.

\section{Matereal And Methods}

This study was carried out on 45 healthy men, according to the age, they were divided into three groups, and each group contains 15 men. The age of Group I, ranged from (50-60) years, Group II: from (61-70) years, Group III: from (71-85) years. The exclusion criteria was, patients with chronic debilitating diseases e.g. cancer anywhere, liver cell failure, renal failure, diabetes mellitus and obesity, also patients under corticosteroid or immunosuppressive therapy. The following parameters were performed for each subject, history and clinical examination. Complete routine laboratory investigations. Blood samples were taken from all studied cases, serum were separated. Estimation of serum total and free testosterone, total and free prostate specific antigen concentration were done on the same day by electrochemiluminescence immunoassay on the Roche Elecsys 1010 on immunoassay
Analyzer, with Elecsys reagent kits, Cat No. 1776061, 1776562, 1731262, 171265 respectively.

Transrectal ultrasonography (TRUS) was performed with high-resolution real time ultrasonography equipment (Simens sono-line Elegra) Equipped with (6.5MHZ ) probe. The size of the prostate was measured, any focal abnormalities were determined. Six systematic biopsies were taken from the focal lesions and histopathological examination was performed to exclude any malignancy. Bone Densitometry were performed with ultrasound bone - imaging scanner UBIS 3000(DMs, Montpellier, France) as described by Van Den Bergh, et al: 2000 (7). The following properties were detected, broad band ultrasound attenuation (BUA, $\mathrm{db} / \mathrm{MH} 2$ ), Speed of Sound (SOS, m/sec), Relative Risk Fracture (RRF). -T-score: (represent the standard deviation (SD) of BUA in reference to normal young age value.). - Z- score: (which represent the $\mathrm{SD}$ of BUA in reference to age matched normal value).

PSA values, erectile function and Bone densitometry parameters, were correlated with testosterone levels either total or free.

RESULTS

Testosterone levels (total and free) statistically decline progressively with age. Although the lowest level of free and total testosterone was found in group III but this level was still within the normal range (Table, 1). 
Table (1) Mean Values \pm SD of Total and Free Testosterone in the Three Studied Groups.

\begin{tabular}{|c|c|c|c|}
\hline Testosterone & Group I & Group II & Group III \\
\hline Total (ng/ml) & $11.85 \pm 1.3$ & $\begin{array}{c}10.8 \pm 1.5 \\
t=-2 \\
P<0.05^{*} S\end{array}$ & $\begin{array}{c}9.66 \pm 1.57 \\
\mathrm{t}=-3.77 \\
\mathrm{P}<0.001 * * \mathrm{HS} \\
\mathrm{t}=-1.97 \\
\mathrm{P}>0.05 * * * \mathrm{~S}\end{array}$ \\
\hline Free $(\mathrm{pg} / \mathrm{ml})$ & $51.8 \pm 4.45$ & $\begin{array}{c}44.07 \pm 3.26 \\
t=-5.4 \\
p<0.0001^{*} \mathrm{HS}\end{array}$ & $\begin{array}{c}36.7 \pm 6,86 \\
\mathrm{t}=-7.4 \\
\mathrm{p}<0.0001 * * \\
\mathrm{t}=-3.99 \\
\mathrm{p}<0.0001 * * * \mathrm{HS}\end{array}$ \\
\hline$*$ & tween gro & & \\
\hline $\begin{array}{l}* * \\
* * *\end{array}$ & tween gro & & \\
\hline
\end{tabular}

Table (1) showed significant declining in total and free testosterone with increasing age.

As regard total testosterone it was significantly higher in group I compared to group II and III $(\mathrm{p}<0.05)$ and $(\mathrm{p}<0.001)$ in both groups respectively, and also decline significantly in group III compared to group II $(\mathrm{p}<0.05)$. As regard free testosterone it was progressively decline significantly in all groups with increasing age. We found positive correlation between total and free testosterone.

Table (2) Mean Values \pm SD of Total and Free PSA in the Three Studied Groups.

\begin{tabular}{|c|c|c|c|}
\hline PSA & Group I & Group II & Group III \\
\hline Total $(\mathrm{ng} / \mathrm{ml})$ & $0.49 \pm 0.25$ & $0.82 \pm 0.12$ & $2 \pm 0.11$ \\
\hline & & $\mathrm{t}=-4.46$ & $\mathrm{t}=-12.39$ \\
& & $\mathrm{P}<0.05 * \mathrm{~S}<0.0001^{*} * \mathrm{HS}$ \\
$\mathrm{t}=-10.98$ \\
& & & $\mathrm{P}<0.0001 * * * \mathrm{HS}$ \\
\hline Free $(\mathrm{pg} / \mathrm{ml})$ & $0.14 \pm 0.16$ & $0.62 \pm 0.13$ & $0.87 \pm 0.18$ \\
\hline & & $\mathrm{t}=-9.27$ & $\mathrm{t}=-9.946$ \\
& & $\mathrm{P}<0.0001 * \mathrm{HS}$ & $\mathrm{p}<0.0001 * * \quad \mathrm{HS}$ \\
& & & $\mathrm{t}=-4.7$ \\
& & & $\mathrm{P}<0.05 * * * \mathrm{~S}$ \\
\hline
\end{tabular}

$\begin{array}{ll}* & \text { Difference between group I and II } \\ * * & \text { Difference between group I and III } \\ * * * & \text { Difference between group II and III }\end{array}$

As regard total PSA it was progressively increased with aging. In comparison of total PSA in all groups we found that, significant increment in-group II compared to group I ( $\mathrm{p}>0.05)$, also in-group III compared to group I ( $\mathrm{p}<0.0001)$.

The same result was found in comparing group III and group II $(\mathrm{p}<0.0001)$.

As regard free PSA we found progressive increment in-group II and group III compared to group I ( $\mathrm{p}<0.0001)$, also significant elevation of its level in- group III compared to group II $(\mathrm{p}<0.05)$. Also we found positive correlation between total and free PSA.

In spite the previous results, the mean values of the total and free PSA in the different three groups were still within the normal range (Table 2).

Additionally an inverse relationship was found between testosterone levels either total or free with PSA values.

There was progressive declining in erectile function in the three studied groups, 


\section{S.I.Enany $\boldsymbol{e t}$ al}

it become more worsening in-group III (table 3). As regard the relation between values of total and free testosterone and erectile function, both were steady decline with aging

Table (3) Relation between Mean Values of Total and Free Testosterone with Erectile Tissue Function In the three Studied Groups

\begin{tabular}{|c|c|c|c|c|c|c|}
\hline GROUPS & Testosterone & & Erectile ti & function & $X^{2}$ & $\mathrm{P}$ \\
\hline & Total ng/ml & Free $\mathrm{pg} / \mathrm{ml}$ & $+\mathrm{Ve}$ & $-\mathrm{Ve}$ & \multirow{4}{*}{12.06} & \multirow{4}{*}{0.002} \\
\hline Group I & $11.85 \pm 1.3$ & $51.8 \pm 4.45$ & $12(80 \%)$ & $3(20 \%)$ & & \\
\hline Group II & $10.8 \pm 1.5$ & $44.07 \pm 3.26$ & $5(33.4 \%)$ & $10(66.6 \%)$ & & \\
\hline Group III & $9.66 \pm 1.57 \mathrm{~s}$ & $36.7 \pm 6,86$ & $3(20 \%)$ & $12(80 \%)$ & & \\
\hline
\end{tabular}

Significant + ve relation was found between erectile function and level of testosterone either total or free, $(\mathrm{p}<0.002)$.

In the current study, BUA in-group II was significantly lower than group I $(\mathrm{p}<0.001)$ but insignificant difference between group II and group III. Relative Risk Fracture (RRF) increased significantly in-group II compared to group I $(p<0.003)$, but with insignificant difference between group II and III ( $>00.998)$. In comparison of T-score in the three studied groups there were highly significant reduction in its level in group II compared to I $(\mathrm{p}<0.001)$, and significant reduction in group III compared to I $(\mathrm{p}<0.02)$, while non significant difference between group II and III ( $>0.38$ ). As regard $\mathrm{Z}$-score their was highly significant reduction in its value in groups II and III compared to group $\mathrm{I},(\mathrm{p}<0.000)$ for both groups, while non significant difference was found between group II and III (table 4).

Table (4) Comparison of Mean Values \pm SD of Bone Densitometry Parameters in The Three Studied Groups.

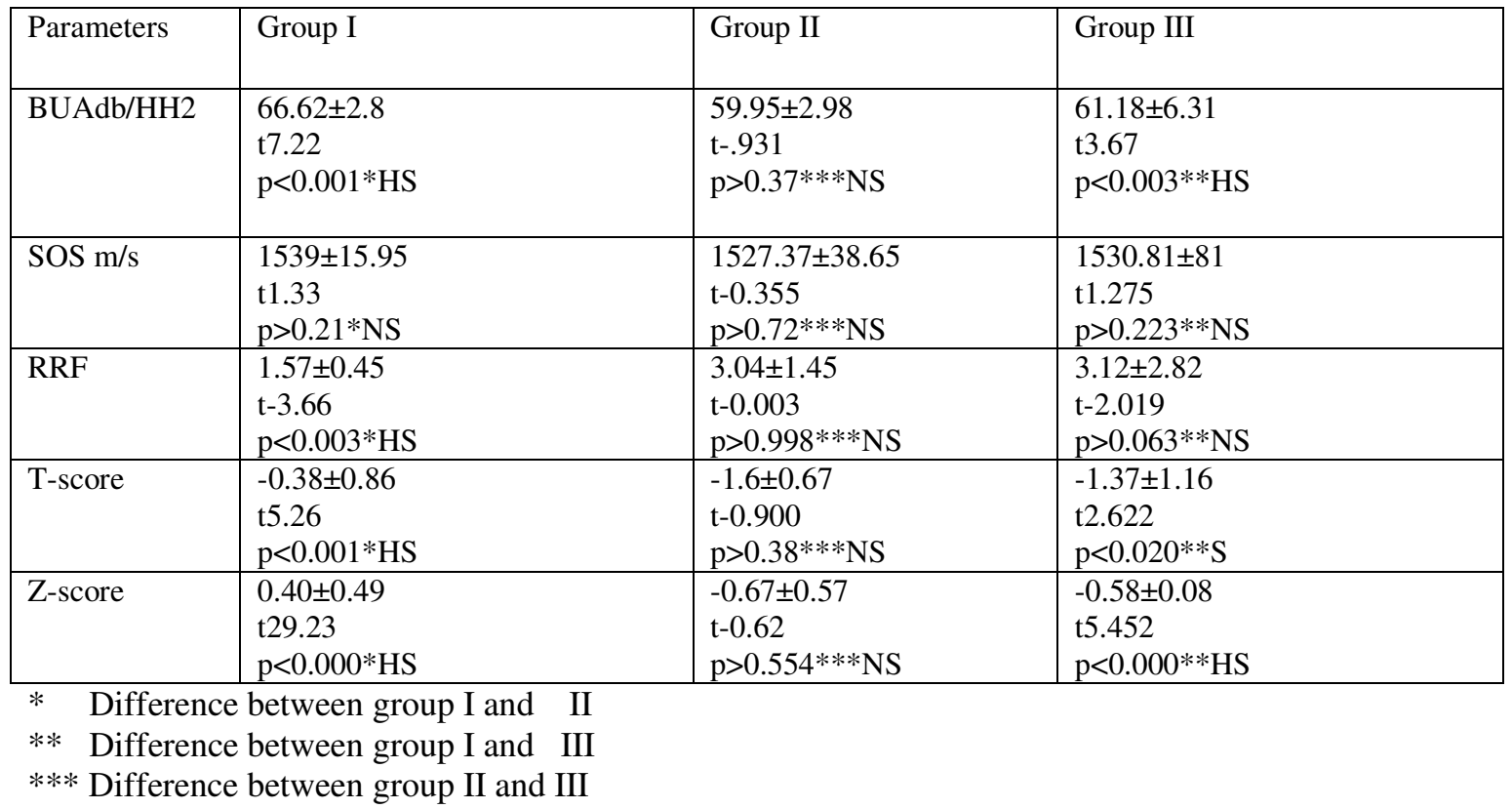


Testosterone (free and total) were correlated with bone densitometry parameters in all studied subjects, the following were found, there was direct significant relation between free testosterone levels versus BUA, T-score and Z-score, while it has inverse relation with RRF. Also significant positive correlations were found between total testosterone versus BUA and T-score, while the relation was negative with RRF.

RRF increased progressively with increasing age, Table (5) .

Table (5) Correlation Between testosterone (total and free) and densitometry parameters in all studied subject

\begin{tabular}{|l|l|l|l|l|l|}
\hline Testosterone & BUA db/HH2 & $\mathrm{SOS} \mathrm{m} / \mathrm{s}$ & $\mathrm{RRF}$ & T-score & Z-score \\
\hline Free $\mathrm{pg} / \mathrm{ml}$ & $\mathrm{r} 0.386$ & $\mathrm{r}-0.296$ & $\mathrm{r}-0.335$ & $\mathrm{r} 0.441$ & $\mathrm{r} 0.401$ \\
& $\mathrm{p}<0.009 * * \mathrm{HS}$ & $\mathrm{p}>0.104$ & $\mathrm{p}<0.024 * \mathrm{~S}$ & $\mathrm{p}<0.002 * * \mathrm{HS}$ & $\mathrm{p}<0.006 * * \mathrm{HS}$ \\
\hline Total $\mathrm{ng} / \mathrm{ml}$ & $\mathrm{r} 0.296$ & $\mathrm{r}-0.079$ & $\mathrm{r}-0.464$ & $\mathrm{r} 0.299$ & $\mathrm{r} 0.275$ \\
& $\mathrm{p}<0.048 * \mathrm{~S}$ & $\mathrm{p}>0.065$ & $\mathrm{p}<0.001 * * \mathrm{HS}$ & $\mathrm{p}<0.046 * \mathrm{~S}$ & $\mathrm{p}>0.086$ \\
\hline
\end{tabular}

* Correlation is significant at 0.05 levels (2-tailed)

** Correlation is highly significant at 0.01 levels (2-tailed)

As regard free testosterone there was significant +ve correlation with BUA, T and Z score but significant -ve correlation was found with RRF.

As regard total testosterone +ve correlation was found with BUA and $\mathrm{T}$ score but $-\mathrm{ve}$ correlation with RRF.

\section{Disscusion}

Recent years have seen an increasing interest in studies of the aging male, with a particular interest in the problem of whether so- called rejuvenating hormones and more specifically androgens which can improve quality of live, counteract progressive skeletal and muscle strength loss, prevent falls and fractures, prolong independent living, and reduce the dependence on medical care (8). The most frequent age for onset of symptoms related to andropause was 51-60 years, where patients reported symptoms such as impotence, weakness and memory loss. The next most common age associated with this problem was $61-70$ years. Smokers are at risk for an earlier onset of andropause (9). A progressive decrease in androgen production is common in aging men. Several studies have shown gradual decline in bioavailable testosterone at age of forty. The physiological causes for this phenomenon seem to be multifactorial (10). There is histological evidence of an aging testicle, with reduced number of Leydig and Sertoli cells (11). The syndrome of androgen deficiency with aging has important biochemical and clinical manifestations (12). Although testosterone levels decline with age, there is great inter individual variability, and the connection between serum testosterone levels and clinical psychiatric signs and symptoms is not clear - cut, since other hormonal changes are implicated as well (13) The changes usually attributed to androgen deficiency have been recognized more recently to be due to a broader problem with a number of interlinked hormonal systems (including growth hormone, insulin- like growth factor- I,melatonin ,and leptin) (12).

In this study we found that, the mean values of the total testosterone was $(11.85 \mathrm{ng} / \mathrm{ml})$ in-group I, $(10.8 \mathrm{ng} / \mathrm{ml})$ ingroup II while it was $(9.66 \mathrm{ng} / \mathrm{ml})$ in-group III. Also the mean values of the free testosterone was $(51.87 \mathrm{pg} . / \mathrm{ml})$ in-group I, $(44.07 \mathrm{pg} / \mathrm{ml})$ in-group II, and $(36.7 \mathrm{pg} . / \mathrm{ml})$ in-group III .Our results revealed that, the mean values of the total and free 


\section{S.I.Enany $\boldsymbol{e t}$ al}

testosterone levels were progressively decline in the three studied groups with increasing age, the lowest level was found in-group III. In spite the gradual decline of testosterone either total or free in all studied groups; but it was still at the accepted normal range.

Endocrine function is steadily declining with aging. At age 75 years the mean plasma testosterone is only $65 \%$ of its levels in young adults, whereas over $25 \%$ of this value is albumen bounded (bioavailable testosterone), its level decrease below the lower normal limit in young adults (14). Free testosterone level begins to decline at a rate of $1 \%$ annually after age of forty (15).

In this work, in spite of the differences in the characteristics of the three studied groups (diets, special habits, stress, body mass index and variation in the timing of blood sampling), their was mild but continuous declining of testosterone levels either total or free with aging, which was more pronounced in group III. Also we believe that, testosterone levels either total or free are not detected below the lower limit of the accepted normal range due to the small frequent number of elderly men were subjected to the study.

Morley, et al, validated a screening questionnaire for androgen deficiency in aging males and reported improvement in male climacteric scores in 18 out of 21 patients on androgen replacement therapy (16). Androgen supplementation may be beneficial in some men aged more than 65 years, particularly with low serum testosterone levels $(<2 \mathrm{ng} / \mathrm{ml})$ (17). Most authors agree that careful evaluation and surveillance of the prostate must attend androgen therapy in aging men (18). Normal serum concentrations of PSA in men aged 50 to 80 years without prostatic disease ranged between (1.0 and $4.0 \mathrm{ng} / \mathrm{ml})$ (19). In the absence of prostate cancer, serum PSA levels vary with age and prostate volume (20). The use of different PSA thresholds depending on age and race, men age from 40 to 50 years have levels lower than $4 \mathrm{ng} / \mathrm{ml}$, but for men age 50 to 60 years, the thresholds are very close to $4 \mathrm{ng} / \mathrm{ml}$ for white males, and 4 to $4.5 \mathrm{ng} / \mathrm{ml}$ for African- American males (21). In men without benign prostatic hyperplasia (BPH), the rate of change in PSA is $(0.04 \mathrm{ng} / \mathrm{ml}$ per year (22), compared to $(0.07$ to $0.27 \mathrm{ng} / \mathrm{ml})$ in men with BPH who are between ages 60 to 85 years (23). This study revealed that, the mean values of the total PSA were (0.49), (0.82) and $(2 \mathrm{ng} / \mathrm{ml})$ in group I, II and III respectively. Also the mean values of free PSA were $(0.14),(0.62)$ and $(0.87)$ $\mathrm{ng} / \mathrm{ml}$ in group I, II and III respectively. So the mean values of the total and free PSA levels in the different studied groups were progressively increased in men with aging, but this increment still within the normal range. The free PSA levels vary directly with age and prostate volume and indirectly with total PSA levels (24). In our results, there is positive correlation between total and free PSA values with aging. The major determinant of serum PSA in men without prostate cancer is the transition zone epithelium, not the peripheral zone of the prostate (25). In our work, all studied groups have PSA levels either total or free at the normal ranges of age - specific PSA levels. We believe that; this result mostly due to that, the total volume of the prostate is not enlarged and the transition zone remains within the normal size. Serum PSA elevations may occur as a result of disruption of the normal prostatic architecture that allows PSA to diffuse into the prostatic tissue and gain access to the circulation. PSA expression is strongly influenced by androgen (26). This study showed that, there is inverse relationship between testosterone either total or free levels and PSA values in the different studied groups.

There are several reasons to justify at least basic hormonal assessment of men with erectile dysfunction. It is commonly accepted that the combination of low sexual desire and erectile difficulties may be the result of serious hormonal abnormalities. The reality is not that clear cut (27). The causal relationship between declining testosterone levels and development of erectile tissue dysfunction is not firmly established. Two studies suggested that while erectile dysfunction showed a clear association with aging, there was no consistent correlation with total plasma 
testosterone (28, 29). Another study reported that androgen insufficiency in the rabbit animal model produced significant loss of trabecular smooth muscle and increased connective tissue deposition but had little effect on neural nitric oxide syntheses expression or activity (30). The castrated animals develop venous leak and veno-occlusive dysfunction and testosterone treatment restore erectile function. The androgen deprivation results in alteration in endothelial cell structure and this may contribute to erectile dysfunction (31). Aversa et al performed a prospective randomized placebo- controlled study in 20 men with erectile dysfunction who failed sildenafil treatment on 6 consecutive attempts and had free testosterone in the lower quartile of the lower range. One month after treatment with transdermal testosterone and sildenafil on demand, they found significant increased score in the erectile function domain of the International Index of Erectile Function (32). In our study, the erectile function is decline with aging. The erectile function was found $(80 \%),(33.4 \%)$ and $(20 \%)$ in group I, II and III respectively. The relation between the mean values of the total and free testosterone and erectile function, were both decline with aging.

Loss of bone mass in men becomes more clinically significant at them live longer (33). The hip fractures rates in men increase dramatically after the age of 60 years and double with each decade thereafter. There is a clear association between decrease in serum free testosterone levels and decline in bone mineral density at the femoral neck (34). Reversal of hypogonadism is associated with improvement in bone mass and maintenance of skeletal integrity (35). Broadband ultrasound attenuation (BUA) was used by many investigators as an index for assessment of bone. Two authors reported that, BUA values decrease with age in both males and females $(36,37)$. These results are in agreement with our results as BUA in-group II was significantly lower than group I $(\mathrm{p}<0.001)$, but with insignificant difference between group II and group III. In the current study we also found significant increase in relative risk fracture (RRF) in-group II compared to group I $(\mathrm{p}<0.003)$, but with insignificant difference between group II and group III ( $P>0.998)$. This result was in agreement with Cummings et al, which found that RRF increased progressively with increasing age (38). As regard comparison of T-score it was significantly lower in elderly compared to young group $(\mathrm{p}<0.001)$. On comparison of BUA using Z- score there was significant reduction in group II and III compared to group I $(\mathrm{p}<0.001)$, but with insignificant difference between group II and III. Katz nelson, et al (39) and Kaufman (40) reported the same result. From these results we confined that bone mineral density decrease gradually with increasing age, and increased incidence of bone fracture. This finding was close and highly significant after the age of sixty years, but the progression become slower after age of 70 years. We recommended that, long term studied on larger number of aging men are required to confirm whether testosterone levels either total or free can be considered a reason factor for decrease of bone mineral density.

\section{Cunclussion}

Testosterone either total or free progressively decline with aging. It is associated with progressive increasing in the levels of total and free PSA with aging. Also, it is accompanied with progressive decline in erectile function. Bone mineral density decreases gradually with increasing age, and increased incidence of bone fracture.

\section{Referances}

1. Morales A., Heaton J.P.W. and Carson C.C.:( 2000) Andropause: A misnomer for a true clinical entity. J. Urol. 163: 705-712.

2. Ferrini R.L. and Barrett-Conner E.: (1998) Sex hormones and age: a crosssectional study of testosterone, estradiol and their bioavailable fractions in community-dwelling men. Am.J.Epidemiol. 147: 750.

3. Cheon J., Sung B.M., Kim J.J., et al: (1998) Osteoporosis in patients received total androgen blockade therapy, for 


\section{S.I.Enany $\boldsymbol{e t}$ al}

prostate cancer. J. Urol. Suppl., 159: 338 Abstract 1298.

4. Bernhard P.H. and Niewoehner C.: (1998) Effects of early hormonal therapy on bone in asymptomatic men have prostate cancer. J.Urol. Suppl, 159: 338 Abstract 1292.

5. 5-Liebenluft E., Schmidt P.J., Turner E.H., et al:( 1997) Effects of leuprolideinduced hypogonadism and testosterone replacement on sleep, melatonin and prolactin secretion in men.J. Clin. Endocrinol. Metab. 82:3203.

6. Wespes E. and Schulman C.C.: (2002) Male andropause: Myth, reality and treatment. Int. J. Impot. Res. 14 :( 1): 93-98.

7. Van Den Bergh JP, Noordam C, Ozyilmaz A, et al:( 2000) Calcaneal ultrasound imaging in healthy children and adolescent: relation of the ultrasound parameters BUA as SOS to age, body weight, height, foot dimensions and pubertal age. Osteoporosis Int. 11 : 967976.

8. Vermeulen A.:( 2001) Androgen replac ement therapy in the aging male: A critical evaluation. J. Clin. Endocrinol. Metab. 86:6: 2380-2390.

9. Tan R.S. and Philip P.S.: (1999) Perceptions of risk factors for andropause. Arch. Androl. 43 (3): 227-233.

10. Leifke E., Gorenoi V., Wichers C., et al :( 2000) Age- related changes of serum sex hormones, insulin-like growth factor-1 and sex- hormone binding globulin levels in men : Cross-sectional data form a healthy male cohrt. Clin. Endocrinol. (Oxf) 53 (6)689-695.

11. 11-Tserotas K. and Merino G.:(1998) Andropause and the aging male. Arch Androl. 40 (2): 87-93

12. Heaton J.P. and Morales A.:( 2001) Andropause- a multisystem disease. J. Urol. 8 (2) : 1213-1222.

13. Sternbach H.:( 2000) Age-associated testosterone decline in men : Clinical issues for psychiatry. Am. J. Psychiatry. 157 (2): 307-8.

14. Vermeulen A.:( 2000) Andropause. Maturties. 34 (1): 5-15.

15. 15-Lund B.C., Bever-Stille K.A. and Perry P.J.:(1999) Testosterone and andropause: the feasibility of testosterone replacement therapy in elderly men. Pharmacotherapy. 19 (8): 951-956.

16. Morley J.E., Charlton E., Patrick P., et al:( 2000) Validation of screening questionnaire for androgen deficiency in aging males. Metabolism. 49(9): 1239-42.

17. Anawalt B.D. and Merriam G.R.:(2001) Neuroendocrine aging in men. Andropause and somtopause. Endocrinol. Metab. North. Am. 30(3): 647-69.

18. Heaton J.P.:( 2001) Andropause: Coming of age for an old concept? Curr. Opin. Urol. 11(6): 597-601.

19. Catalona W.J., Smith D.S., Ratliff T.L.et al:( 1991) Measurement of prostate specific antigen in serum as a screening test for prostate cancer. N. Engl. J. Med. 324: 1156- 1161.

20. Carter H.B. and Partin A.W.:( 2002) Diagnosis and staging of prostate cancer. Compbell's Urology 8th edition. Editor by Walsh. Et al W.B.Saunders. Philadelphia. Vol.6: p3055.

21. Morgan T.O., Jacobsen S.J., McCarthy W.F., et al :(1996) Age specific reference ranges for prostate specific antigen in black men. N.Engl.J. Med. 335:304.

22. Oesterling J.E., Jacobsen S.J., Chute C.G., et al :(1993) Serum prostate specific antigen in a community based population of healthy men :Establishment of age specific reference ranges. JAMA. 270:860.

23. 23-Carter H.B., Pearson J.D., Metter J.E.et al : (1992) Longitudinal evaluation of prostate specific antigen levels in men with and without prostate disease. JAMA $267: 2215$.

24. 24-Woodrum D.L.,Brawer M.K., Partin A.W.et al ( 1998) Interpretation of free prostate specific antigen clinical research studies for the detection of prostate cancer .J. Urol. 159: 5.

25. Lepor.H., Wang B.,Shaprio E.:(1994) Relationship between prostatic epithelial volume and serum prostate specific antigen levels. Urology 44: 199.

26. 26-Young C.Y.,Montgomery B.T., Andrews P.E., et al :(1991) Hormonal regulation of prostate specific antigen messenger RNA in human prostatic adenocarcinoma cell line LN CaP. Cancer Res. 51: 3748.

27. Morales A., Johnston B.,Heaton J.P.W., et al: (1997) Testosterone supplementation in hypogonadal impotence: assessment of biochemical measurements and therapeutic outcomes. J.Urol. 157: 849.

28. Rhoden E.I., Teloken C.,Sogari P.R.and Souto C.A. : (2002) The relationship of serum testosterone to erectile function in normal aging men .J. Urol. 167 :1745-1748. 
29. Rhoden E.I., Teloken C., Mafessoni R. and Souto C.A.:( 2002) Is there any relation between serum levels of total testosterone and the severity of erectile dysfunction. Int. J. Impotence. Res.14: 167171.

30. Traish A.M., Munarriz R., O'connell L.,et al : 2003 Effects of medical and surgical castration on erectile function in an animal model. J. Androl. 24:381-387.

31. Rogers R.S., Graziottin T.M. ,Lin C.M., et al :(2003) Intracavernosal vascular endothelial growth factor (VEGF) injection and adeno-associated virus- mediated VEGF gene therapy prevent and reverse venogenic erectile dysfunction in rats. Int. J. Impot. Res. 15 : 26-37.

32. Aversa A., Isidori A.M.,Spera G., et al :(2003) Androgens improve cavernous vasodilation and response to sildenafil in patients with erectile dysfunction. Clin. Endocrinol. (Oxf). 58: 632-638.

33. Basaria S. and Dobs A.S.:(1999) Risks versus benefits of testosterone therapy in elderly men. Drugs and Aging. 15(2): 131142.

34. 34-Orwoll E.S.,Oviatt S.,McCLang M.R., et al :(1990) The rate of bone mineral loss in normal men and the effects of calcium and cholecalciferol supplementation. Ann Intern. Med. 112: 29-34.
35. 35-Ongphiphadhanakul B.,Rajatanavin R., Chailurkt L.,et al : ( 1995) Serum testosterone and its relation to bone mineral density and body composition in normal males. Clin. Endocrinal. 43: 727-733.

36. Shott A M, Hans D, Sornay- Rendu E, et al: (1993 ) Ultrasound measurements on oscalcis precision and age related changes in a normal female population. Osteoporosis Int. $3: 249-254$.

37. Stewart A and Porter R: (1994) Broad bond ultrasound attenuation and dual energy $\mathrm{x}$ - ray absorptiometry in patients with hip fracture risk. Calcif. Tissue. Int. 54: 466-67

38. Cummings SR, Black MD, Nevitt E et al: (1993) Bone density at various sites for prediction of hip fractures. Lancet. 341:7275

39. Katz nelson L, Finkelstein JS, Schoenfeld DA :( 1996) Increase in bone density and lean body mass during testosterone administration in men with acquired hypogonadism. J. Clinical Endocrinology and Metab.81: 4358

40. Kaufman JM: (1996) Androgens and the aging male, bone metabolism and osteoporosis, (eds) Vermeulen A, New York, Parthenon, publishing Group, p 39 


\section{S.I.Enany $\boldsymbol{e t}$ al}

\section{الأهمية الإكلينيكية للتستوسترون الكلى والحر مع تقدم السن في الرجال}

سيدة عناتي * ـ هناء طة قنديل***. نائلة عبد اللطيف **** ـ ماجدة حسين $* * * *$

من اقسام جر احة المسالك البولية *.الغدد الصماء **. الاشعة التشخيصية ***. الباثولوجيا الاكلينيكية*****

كلية الطب - جامعة الازئرة هر

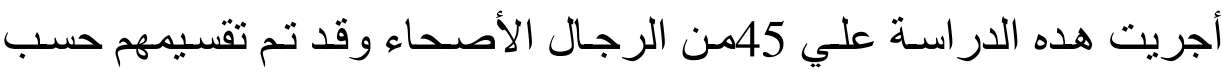

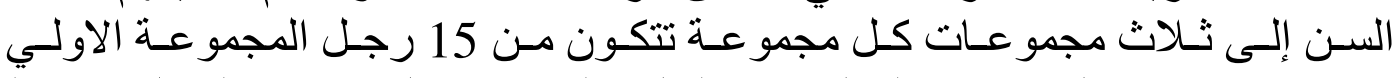

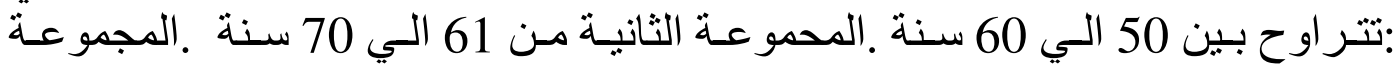

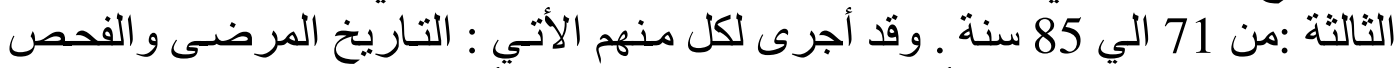

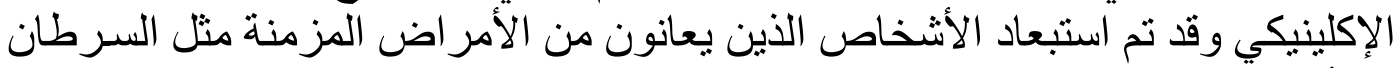

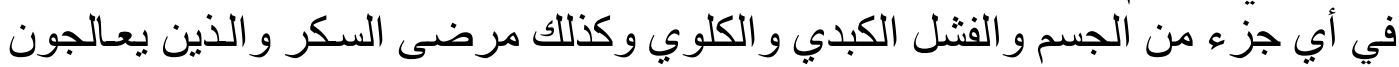

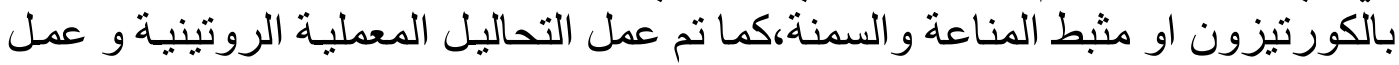

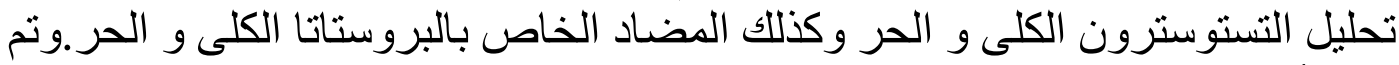

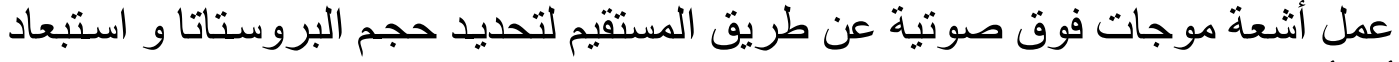

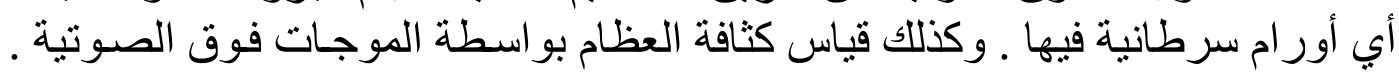

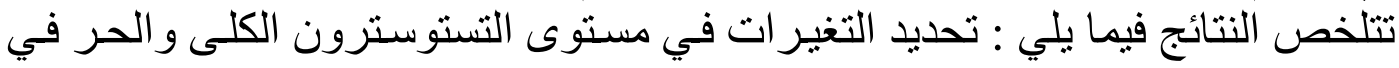

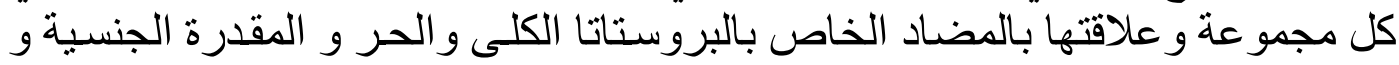

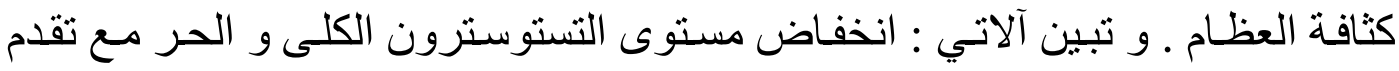

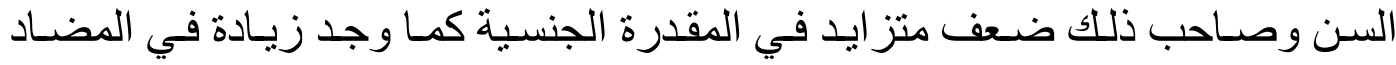
الخاص بالبروستاتا الكلى و الحر مع تقدم السن وكذللك زيادة في نسبة هشانثة الَّظام. 